\title{
KONSTRUKSI HAK MENGUASAI NEGARA DALAM TATA LAKSANA PENGADAAN TANAH BAGI KEPENTINGAN UMUM DI KABUPATEN SEMARANG
}

\author{
Sumral Buru Manoe \\ Kepala kantor Badan Pertanahan Nasional kabupaten Grobogan \\ sumralbn00@yahoo.com
}

\begin{abstract}
In the implementation of land acquisition for public purposes (project Semarang-Solo toll road) there has been a priority of the State's Rights. implementation of the State's rights to land are not always parallel with the ideals of prosperity, welfare and even justice. The phenomenon of the right to control the state, namely the practice of takeover of the land belongs to the people in the name of public interest and or preferential right to control the country and even a common trigger factor land conflict. In the development of the law is not only focused on textuality laws alone but must also pay attention to the interests of the community that continues to grow, especially related to land issues. This study uses socio-legal research approach, meaning that not only reviewing an issue of legislation but also the reality that occurs in the community related to the problems discussed. the results obtained to mention that the process of land acquisition for the construction of the Semarang-Solo toll road in accordance with procedures applicable law, namely to put the negotiation process (consensus), especially about the amount of compensation awarded. However, a strong indication of consensus is not performed substantially, only meets the provisions of the Act alone.
\end{abstract}

Keywords: The State's Rights, Land Acquisition, Public Interest, Change Fortunately, Welfare.

\begin{abstract}
Abstrak
Dalam pelaksanaan pengadaan tanah untuk kepentingan umum (proyek jalan tol SemarangSolo) telah terjadi pengutamaan Hak Menguasai Negara. implementasi hak menguasai negara atas tanah tidak selalu paralel dengan cita-cita kemakmuran, kesejahteraan dan bahkan keadilan. Fenomena semacam egologi hak menguasai negara, yaitu praktek ambil alih terhadap tanah milik masyarakat atas nama kepentingan umum dan atau pengutamaan hak menguasai negara sering terjadi dan bahkan merupakan faktor pemicu konflik pertanahan. Dalam perkembangannya hukum tidak hanya terfokus pada tekstualitas undang-undang semata namun juga harus mampu memperhatikan kepentingan-kepentingan dalam masyarakat yang terus berkembang terutama terkait persoalan tanah. Penelitian ini menggunakan metode pendekatan socio legal research, artinya tidak hanya meninjau suatu permasalahan dari peraturan perundang-undangan saja tetapi juga kenyataan yang terjadi dalam masyarakat kaitannya dengan permasalahan yang dibahas. hasil penelitian yang diperoleh menyebutkan bahwa proses pengadaan tanah untuk pembangunan jalan tol Semarang-Solo dilakukan sesuai prosedur hukum yang berlaku, yakni dengan mendahulukan proses negosiasi (musyawarah mufakat), terutama soal besarnya ganti rugi yang diberikan. Namun demikian, kuat indikasi musyawarah mufakat tidak dilakukan secara substansial, hanya sekedar memenuhi ketentuan Undang-undang semata.
\end{abstract}

Kata kunci: Hak Menguasai Negara, Pengadaan Tanah, Kepentingan Umum, Ganti Untung, Kesejahteraan. 


\section{A. PENDAHULUAN}

Dalam praktek, implementasi hak menguasai negara atas tanah tidak selalu paralel dengan cita-cita kemakmuran, kesejahteraan dan bahkan keadilan. Fenomena semacam egologi hak menguasai negara, yaitu praktek ambil alih terhadap tanah milik masyarakat atas nama kepentingan umum dan atau pengutamaan hak menguasai negara sering terjadi dan bahkan merupakan faktor pemicu konflik pertanahan. Maria S.W. Sumardjono mencatat jenis konflik pertanahan yang sangat dominam di Indonesia dalam 2 (dua) dekade terakhir adalah soal penguasaan tanah dan soal ganti rugi pengadaan tanah bagi kepentingan umum, di samping status kepemilikan dan penggunaan tanah. ${ }^{1}$ Studi yang dilakukan oleh Bernhard Limbong juga menjustifikasi akar dari konflik pertanahan disebabkan oleh 2 (dua) hal mendasar. Pertama, faktor umum menyangkut faktor hukum dan non hukum antara lain: tumpang tindihnya peraturan, regulasi kurang memadai, birokrasi yang berbelitbelit, tumpang tindih penggunaan tanah, nilai ekonomis tanah yang tinggi, pertambahan pendudukan dan kemiskinan. Kedua, faktor khusus menyangkut kasus penguasaan tanah oleh negara, kasus tanah objek landreform, dan kasus pengadaan tanah bagi kepentingan umum. ${ }^{2}$ Faktor hukum sebagai salah satu sumber konflik pertanahan selain ditandai oleh tumpang tindihnya aturan, juga karena substansi aturan yang mengedepankan pendekatan keamanan (security approach) dan pendekatan hukum (legality approach).

Sejarah perundang-undangan yang mengatur pembebasan atau pengadaan tanah mencatat bahwa peraturan perundangan yang ada, tidak lebih dari sekedar instrumen untuk mengambilalih tanah masyarakat atas nama kepentingan umum atau kepentingan pembangunan. Di bawah Undang-undang Nomor 20 Tahun 1961, Keputusan Presiden Nomor 55 Tahun 1993 Tentang Pengadaan Tanah Bagi Kepentingan Umum, Peraturan Presiden Nomor 36 Tahun 2005 yang kemudian diubah dengan Peraturan

1 Maria S.W. Sumardjono, Sengketa Pertanahan dan Penyelesaian Secara Hukum, dalam Elza Syarif, Menuntaskan Sengketa Tanah, hlm. 31.

2 Bernhard Limbong, 2012, Konflik Pertanahan, Pustaka Margaretha, Jakarta, hlm 63.
Presiden Nomor 65 Tahun 2006, tidak hanya kepentingan umum yang multi tafsir, tetapi juga roh yang menjiwai peraturan perundangan tersebut jauh dari cita-cita kesejahteraan dan keadilan.

Secara hipotesis semangat menggusur dalam peraturan perundangan yang mengatur tata kelola pengadaan tanah bagi kepentingan umum, bermula ketika terjadi pergeseran makna hak menguasai negara dari penguasaan serba publik ke penguasaan serba privat. Kondisi yang demikian telah berlangsung dalam 5 (lima) dekade terakhir. Eksesnya bagi hak menguasai negara terhadap bumi (tanah) adalah pereduksian hak menguasai negara sekedar masalah tatakelola (beheersdaad) dan pengaturan (regelendaad) semata. Penguasaan negara terhadap tanah yang azasinya sebagai penguasaan terhadap barang publik (public goods) untuk dipergunakan sebesar-besarnya bagi kemakmuran rakyat direduksi dengan cara mengindentikkannya dengan kepentingan nasional atau kepentingan umum yang multi interpretatif. Konsep asasi penguasaan negara terhadap public goods sebagai manisfestasi falsafah republikan, dalam banyak kasus diinterpretasikan secara monolitik sesuai selera penguasa.

Beranjak dari adagium "demi kepentingan umum", tidak jarang terjadi tindakan pengambilalihan/pencabutan/pelepasan hak atas tanah yang dipaksakan dan bahkan melanggar hak asasi manusia. Hal yang sama terjadi dalam regulasi Undang-undang Nomor 2 Tahun 2012 yang secara khusus mengatur tata laksana pengadaan tanah bagi kepentingan umum. Selain sangat rawan diselewengkan untuk kepentingan bisnis yang justru meminggirkan akses publik terhadap hasil pembangunan, juga rohnya yang mengedepankan pendekatan hukum dan keamanan. Berdasarkan uraian tersebut di atas, maka penulis merumuskan masalah sebagai berikut:

1. Bagaimanakah konstruksi hak menguasai negara dalam tata laksana pengadaan tanah bagi kepentingan umum di Kabupaten Semarang?

2. Bagaimanakah hambatan-hambatan dan solusinya yang dilakukan dalam menterjemahkan konstruksi hak menguasai negara yang ideal dalam tata laksana 
pengadaan tanah bagi kepentingan umum di Kabupaten Semarang?

\section{B. METODE PENELITIAN}

Penelitian ini menggunakan metode pendekatan socio legal research, artinya tidak hanya meninjau suatu permasalahan dari peraturan perundang-undangan saja tetapi juga kenyataan yang terjadi dalam masyarakat kaitannya dengan permasalahan yang dibahas

\section{HASIL PENELITIAN DAN PEMBAHASAN}

1. Konstruksi Hak Menguasai Negara Dalam Tata Laksana Pengadaan Tanah Bagi Kepentingan Umum Di Kabupaten Semarang.

Secara normatif proses pengadaan tanah untuk pembangunan jalan tol Semarang-Solo dilakukan sesuai prosedur hukum yang berlaku, yakni dengan mendahulukan proses negosiasi (musyawarah-mufakat), terutama soal besarnya ganti rugi yang diberikan. Namun demikian, sulitnya mencapai kesepakatan soal besarnya ganti kerugian merupakan sebab utama lambat proses pembebasan.

Berdasarkan Pasal 37 Peraturan Kepala Badan Pertanahan Nasional Nomor 3 Tahun 2007 Tentang Petunjuk Pelaksanaan Peraturan Presiden Nomor 36 Tahun 2005 j.o. Peraturan Presiden Nomor 65 Tahun 2006 Tentang Pengadaan Tanah bagi Pelaksanaan Pembangunan untuk kepentingan umum (yang menjadi rujukan dalam kasus pengadaan tanah untuk jalan tol pada Undang-Undang Nomor 2 Tahun 2012), secara limitatif menentukan:

a. Musyawarah dilakukan dalam waktu 120 hari kalender terhitung sejak tanggal undangan;

b. Jika kesepakatan telah mencapai $75 \%$ maka Instansi Pemerintah sudah dapat membayarkan ganti rugi.

Dengan merujuk berbagai ketentuan perundangan penentuan nilai tanah dan hasil penilaian Appraisal Independen, TPT menetapkan nilai tanah dengan memperhatikan beberapa faktor sebagai berikut:

a. Jenis tanah (pekarangan atau tanah sawah, tegalan dan lain-lain);

b. Lokasi tanah;

c. Status penguasaan;

d. Peruntukan;

e. Sarana yang tersedia;

f. Fasilitas dan utilitas, serta

g. Lingkungan.

Pengadaan tanah untuk kepentingan umum sebagaimana di uraikan di atas mengindikasikan 2 (dua) hal mendasar, jika dikaitkan dengan konstruksi hak menguasai negara.

a. Bahwa hak menguasai Negara dalam tata laksana pengadaan tanah selalu diutamakan atau bersandar pada doktrin pengutamaan (egologi) kekuasaan negara. Doktrin ini dapat dibaca dari adanya legitimasi yang diberikan kepada negara (Pemerintah, Pemerintah Daerah) untuk mengambil-alih tanah-tanah yang ditelantarkan termasuk tanah negara (vide pasal 3 Undang-Undang No. 51 Prp Tahun 1960).

b. Bahwa pengutamaan hak menguasai negara juga terkait erat dengan fungsi sosial tanah sehingga atas nama kepentingan umum dan melalui institusi Hak Menguasai Negara, Pemerintah atau Pemerintah dapat melakukan pencabutan hak-hak tanah yang dimiliki warga negara demi dan untuk kepentingan umum (pasal 18 Undang-Undang Pokok Agraria). Syarat yang terutama ialah harus ada klausul kepentingan umum. Suatu pengambilan hak atas tanah atau suatu kegiatan yang dianggap sebagai suatu pengambilan hak atas tanah tidak dibenarkan tanpa klausul kepentingan umum dimaksud.

Secara teoritis asal usul kekuasaan atau penguasaan negara terhadap tanah setidaknya dapat dijelaskan dari pandangan teori kedaulatan (sovereignty atau souvereniteit), khususnya soal 
siapa yang berdaulat atau memegang kekuasaan dalam sebuah negara. Untuk menjawab pertanyaan siapa yang berdaulat beberapa teoritisi menjelaskan sebagai berikut:

a. Van Vollenhoven sebagaimana ditulis oleh Notonagoro negara ialah sebagai organisasi tertinggi dari bangsa yang diberi kekuasaan untuk mengatur segala-galanya dan negara berdasarkan kedudukannya memiliki kewenangan untuk membuat peraturan hukum. ${ }^{3}$

b. J.J. Rousseau menyebutkan bahwa kekuasaan negara sebagai suatu badan atau organisasi rakyat bersumberkan dari hasil perjanjian masyarakat (contract social) yang intinya merupakan suatu bentuk kesatuan yang membela dan melindungi kekuasaan bersama, kekuasaan pribadi dan milik setiap individu. ${ }^{4}$

Dalam perjanjian masyarakat itu, pada hakekatnya yang dilepaskan oleh setiap individu dan diserahkan kepada komunitasnya hanya sebahagian kekuasaan bukan kedaulatannya. Namun kekuasaan negara itu, bukanlah kekuasaan mutlak (postestas legibus omnibus soluta) karena terdapat beberapa ketentuan hukum yang mengikat dirinya seperti hukum alam dan hukum Tuhan (leges nature et devinae) serta hukum yang umum pada semua bangsa yang dinamakan leges imperii.

Pengertian leges imperii menurut Yudha B. Ardhiwisastra ${ }^{5}$ ialah Undang Undang Dasar negara yang berisi ketentuan-ketentuan kepada siapa kekuasaan itu diserahkan dan batas-batas perlaksanaannya. Negara menurut teoritisi

3 Notonagoro, 1984, Politik Hukum dan Pembangunan Agraria di Indonesia, Bina Aksara, Jakarta, hlm 99

4 J.J. von Schmid, 1958, Ahli-ahli Pikir Besar tentang Negara dan Hukum, (terjemahan R. Wiratno, D.Dt. Singomangkuto dan Djamadi), Pembangunan, Jakarta, hlm 176.

5 Yudha B. Ardhiwisastra, 1999, Imunitas Kedaulatan Negara di Forum Pengadilan Asing, Alumni, Bandung, hlm 30. di atas dipandang sebagai territoriale publieke rechtsgemeenschap van overheid en onderdanen, ${ }^{6}$ (wilayah hukum publik adalah warga negara dan pemerintah) yang memiliki karakter sebagai suatu lembaga masyarakat hukum, sehingga kepadanya diberikan wewenang atau kekuasaan untuk mengatur, mengurus dan memelihara (mengawasi) pemanfaatan seluruh potensi sumber daya alam (natural resources) yang ada dalam wilayahnya secara dalaman. Dalam kaitannya dengan hak penguasaan negara atas sumber daya alam khususnya tanah, maka objek kekuasaan negara yang relevan menurut Montesquieu ialah kekayaan (things) sedangkan menurut Roscoe Pound adalah benda-benda (objek kekayaan) karena keduanya merupakan sumber perekonomian negara dan pokok-pokok kemakmuran rakyat. Selaras dengan itu, Bertrand Russel mengatakan dalam sebuah negara, penguasaan terhadap bidang ekonomi tergantung dan ditentukan oleh hukum negara. ${ }^{7}$

Atas nama hukum, negara dapat melakukan hubungan hukum dengan tanah seperti halnya subjek hukum perseorangan. Hubungan hukum negara dengan tanah masuk kategori benda atau tanah yang dipergunakan bagi umum (res publicae). Dengan demikian, jalan umum adalah milik negara. Beberapa alasan dikemukakan: Pertama, adanya hubungan hukum khusus antara negara dengan tanah-tanah yang masuk kategori res publicae in publico usu, yang merupakan penyimpangan dari res publicae in patrimonio (benda-benda yang menjadi kekayaan masyarakat umum); Kedua, kekuasaan hukum yang dijalankan negara terhadap tanah khususnya yang dipergunakan oleh umum, mempunyai

6 Ronald Z. Titahelu, 1993, Penetapan AsasAsas Hukum Umum Dalam Penggunaan Tanah Untuk Sebesar-besar Kemakmuran Rakyat, Disertasi, PPS-UNAIR, Surabaya, hlm 141.

7 Bertrand Russel, 1988, Kekuasaan Sebuah Analisis Sosial Baru, Yayasan Obor Indonesia, Jakarta, hlm 89. 
isi yang sama dengan kekuasaan yang dilakukan negara terhadap tanah- tanah lain yang digunakannya secara tidak terbatas. Isi kekuasaan ini memiliki karakter yang sama dengan kekuasaan dalam milik perseorangan di dalam hukum perdata; Ketiga, tanah yang dipergunakan untuk kepentingan pekerjaan pelayanan umum seperti bangunan kantor pemerintah, termasuk res publicae in publico usu sehingga menjadi milik negara". Dengan demikian, egologi Hak Menguasai Negara tidak saja berdasar wewenang yang ditentukan menurut hukum, melainkan juga meliputi kompetensi dengan kemampuan memikul hak dan kewajiban negara yang sama dengan manusia alamiah. Sebagai konsekuensi logis dari pengutamaan doktrin hak menguasai negara, pendekatan yang dominan pun dalam tata laksana pengadaan tanah untuk kepentingan umum adalah pendekatan hukum (legality approach). Berturut-turut pengutamaan Hak menguasai Negara dan pendekatan hukum (bahkan keamanan) dalam tata laksana pengadaan tanah untuk kepentingan umum (kasus pembebasan tanah untuk jalan tol Semarang-Solo di kabupaten Semarang). Sebenarnya kelengkapan peraturan (mulai dari Undang-Undang, Peraturan Pemerintah. Instruksi Presiden, sampai Peraturan Menteri) mengenai proses pengadaan tanah bagi kepentingan umum, sudah relatif memadai. Pasal 18 UndangUndang Pokok Agraria dengan jelas menyatakan untuk pengadaan tanah bagi kepentingan umum, hak-hak atas tanah dapat dicabut dengan memberi ganti kerugian yang layak dan menurut cara yang diatur dengan undang-undang. Untuk mengoperasionalkan pasal ini, sudah diterbitkan pula peraturan pelaksanaannya, yakni Undang-Undang Nomor 20 Tahun 1961 Tentang Pencabutan Hak-Hak Atas Tanah dan Benda-Benda yang ada di Atasnya.

Undang-Undang tersebut kemudian dilengkapi lagi dengan 2 (dua) aturan pelaksanaan, yakni Peraturan Pemerintah Nomor 39 Tahun 1973 Tentang Acara Penetapan Ganti Rugi oleh Pengadilan Tinggi sehubungan dengan pencabutan hak-hak atas tanah dan benda-benda yang ada di atasnya. Kelanjutannya adalah Instruksi Presiden Nomor 9 Tahun 1973 Tentang Pelaksanaan Pencabutan HakHak atas Tanah dan Benda-Benda yang ada di Atasnya, sedangkan peraturan yang paling operasional adalah Peraturan Menteri Dalam Negeri Nomor 15 Tahun 1975 tentang Ketentuan-Ketentuan Mengenai Tata Cara Pembebasan Tanah.

Terakhir Undang-Undang yang baru yang telah menggantikan semua peraturan perundangan tersebut adalah UndangUndang Nomor 2 Tahun 2012, yang ketika pengadaan tanah untuk jalan tol Semarang-Solo belum diberlakukan. Tidak bisa dipungkiri, dengan tiadanya aturan hukum yang ketat dan komprehensif, maka naluri kekuasaan akan berpeluang berkembang. Kata Lord Acton: "Power tends to corrupt, and absolute power corrups absolutely". Sebagai negara modern yang memiliki institusi-institusi demokrasi, maka sudah seharusnya managemen penyelenggaraan hukum harus ditopang oleh mekanisme hukum yang jelas dan ketat. Ini kian relevan di tengah budaya kekuasaan di Indonesia yang belum cukup tegas membedakan norma dan nilai untuk dunia/urusan publik dan dunia privat. Budaya itulah yang menjadi salah satu sebab mengapa hampir semua ruang kekuasaan di negeri ini sarat dengan praktik KKN.

2. Hambatan dan solusi dalam menterjemahkan konstruksi hak menguasai negara yang ideal dalam tata laksana pengadaan tanah bagi kepentingan umum di Kabupaten Semarang.

Terdapat hambatan yang terdapat dalam tata laksana pengadaan tanah untuk kepentingan umum (proyek pembangunan jalan tol Semarang-Solo), sebagai berikut: 
1. Level Institusional

Permasalahan yang tergolong hambatan dalam proses pengadaan tanah pada aras institusi diindikasikan oleh 2 (dua) hal, yaitu:

a. Masalah alat bukti pemilikan dan penguasaan tanah, antara lain:

1. Karena Warga Terkena Proyek (WTP) menguasai tanah berdasarkan segel jual beli bawah tangan, sementara sertifikat masih atas nama pemilik lama yang sudah tidak diketahui keberadaannya; dan

2. WTP menguasai tanah atas dasarjual belidibawahtangan, sertifikat masih atas nama pemilik lama, tetapi karena kendala aturan pembeli yang menguasai tanah tidak dapat dipertimbangkan untuk menerima ganti rugi.

Pada tahap implementasi, hambatan atau prolematika level institusional tersebut membawa dampak yang signifikan. Selain diindikasikan oleh ketidak-sepakatan oleh WTP, prosedur birokrasi yang berbelit-belit juga tak urung menjadi hambatan

2. Level Masyarakat Warga

Hambatan yang terbilang klasik pada level masyarakat warga adalah soal nilai besarnya ganti kerugian. Hampir tidak pernah ada proses pembebasan tanah di manapun yang mulus karena masyarakat warga serta merta menerima ganti kerugian yang ditetapkan oleh pemerintah. Artinya, hambatan yang sangat menonjol pada level masyarakat warga adalah soal besarnya ganti kerugian. Seperti yang diungkapkan oleh Ngatiyono, ${ }^{8}$ bahwa ada level masyarakat warga juga ditemui beberapa hambatan, seperti:

8 Wawancara dengan Ngatiyono, Kepala Tim pembebasan lahan jalan Tol Semarang-Solo, pada tanggal 20 Juli 2013, jam 14.00 WIB. a. Jual beli yang tidak segera dibalik nama sehingga secara hukum menyulitkan pemberian ganti rugi;

b. Tanah-tanah yang ahli waris sudah tidak ditemukan, sementara tanah dalam keadaan dikuasai okmum tertentu yang tidak ada hubungan hukum dengan tanah;

c. Jual beli di bawah tangan terhadap tanah dengan Leter $\mathrm{C}$;

d. Adanya masyarakat yang sama sekali tidak mau pindah, dipindahkan dan atau menerima ganti rugi.

\section{PENUTUP}

\section{Kesimpulan}

a. Konstruksi Hak Menguasai Negara Dalam Tata Laksana Pengadaan Tanah Bagi Kepentingan Umum Di Kabupaten Semarang Dalam tata laksana pengadaan tanah untuk kepentingan umum (proyek jalan tol Semarang-Solo) telah terjadi pengutamaan Hak Menguasai Negara, di samping pengutamaan pendekatan hukum dan keamanan yang diindikasikan oleh beberapa hal sebagai berikut:

(a) Proses pengadaan tanah untuk pembangunan jalan tol SemarangSolo dilakukan sesuai prosedur hukum yang berlaku, yakni dengan mendahulukan proses negosiasi (musyawarah-mufakat), terutama soal besarnya ganti rugi yang diberikan. Namun demikian, kuat indikasi musyawarah mufakat tidak dilakukan secara substansial, hanya sekedar memenuhi ketentuan Undangundang semata.

(b) Kasus eksekusi (baca, pencabutan hak atas tanah di Desa 'Lemah Ireng' meninggalkan minimal 3 (tiga) catatan penting, yakni (1) lembaga pencabutan hak lebih dikedepankan daripada 
musyawarah, (2) tiadanya pilihan bagi masyarakat pemilik tanah selain menerima uang ganti rugi yang dititipkan di Pengadilan, yang secara sepihak dianggap telah sesuai dengan harga pasaran dan harga ril berdasarkan zona nilai tanah, dan (3) bahwa acara negosiasi atau musyawarah mufakat untuk menentukan besar ganti kerugian lebih sebagai prosedur normatif semata-mata. Akibatnya, jarang menyentuh aspek substansi. Ketika terjadi dead lock, sudah ada prosedur standar yang legal secara hukum, yakni lembaga pencabutan hak.

b. Hambatan-hambatan dan Solusinya Yang Dilakukan Dalam Menterjemahkan Konstruksi Hak Menguasai Negara Yang Ideal Dalam Tata Laksana Pengadaan Tanah Bagi Kepentingan Umum Di Kabupaten Semarang ditemukan dalam kasus pengadaan tanah untuk kepentingan umum (jalan tol Semarang-Solo) di Kabupaten Semarang terjadi pada 2 (dua) level, yakni:

a. Level Institusional

b. level masyarakat warga.

\section{Saran}

a. Perlu menindaklanjuti UndangUndang Tentang Pengadaan Tanah Bagi Kepentingan Umum dengan Peraturan Perundangan yang lebih operasional secara substantive dengan mengedepankan kepentingan para pemilik tanah/ lahan secara nyata, sehingga tidak terjadi tindakan manipulasi, intimidatif dan pencurangan lainnya;

b. Perlu melibatkan masyarakat pemilik tanah/lahan dalam system Panitia Pengadaan Tanah untuk kepentingan umum, agar dapat berperan secara aktif didalam penentuan segala kebijakan mulai dari proses penetapan lokasi sampai penentuan ganti rugi dan atau ganti untung baik itu terhadap tanah/lahan, tanaman dan bangunan;

\section{DAFTAR PUSTAKA}

\section{a. Buku-buku:}

Abdurrahman, 1978, Masalah Pencabutan Hak-Hak Atas Tanah dan Pembebasan Tanah di Indonesia, Alumni, Bandung.

Adam Podgorecki, 1996, Totalitarian Law: Basic Consepts and Issues, dalam Totalitarian and Post-Totalitarian Law, Pogorecki \& Oligiati (eds.) Uraian menyeluruh tentang hukum totalitarian.

Adnan Buyung Nasution, Ed., Eko Budihardjo, 1992, Beberapa aspek Hukum dalam masalah Pertanahan Dan Pemukiman di Kota Besar, Alumni, Bandung.

Agus Salim, 2001, Teori dan Paradigma Teori Sosial (Dari Denzin Guba dan Penerapannya), Tiara Wacana Yogya, Yogyakarta.

Ali Achmad Chomzah, 2003, Hukum-Hukum Pertanahan, Prestasi Pustaka, Jakarta.

Bambang Waluyo, 1991, Penelitian Hukum Dalam Praktek, Sinar Grafika, Jakarta.

Bertrand Russel, (terjemahan Hasan Basri), 1988, Kekuasaan Sebuah Analisis Sosial Baru, Yayasan Obor Indonesia, Jakarta.

Bernhard Limbong, 2012, Konflik Pertanahan, Pustaka Margaretha, Jakarta.

Boedi Harsono, 1995, Hukum Agraria Indonesia: Himpunan Peraturan-Peraturan Hukum Tanah, Djambatan, Jakarta. 
Brahmana Adhie, Menggala, Hasan Basri Nata, 2002, Reformasi Pertanahan: Pemberdayaan hak-hak atas tanah ditinjau dari aspek hukum, sosial, politik, hankam, teknis, agama dan budaya, Mandar Maju, Bandung.

Brugink, J.J.H., 1996, Refleksi Tentang Hukum, Terjemahan Bernard Arif Sidarta, Citra Aditya Bakti, Bandung.

Darwin Ginting, 2010, Hukum Kepemilikan Hak Atas Tanah Bidang Agribisnis: Hak Menguasai Negara Dalam Sistem Hukum Pertanahan Nasional, Ghalia Indonesia, Bogor.

David Butcher, Draft 30 September 1988, Impact and Trade-offs of Hydropower on Sustainable Development in the Tropicts and Sub-tropicts: The Impact of Dam Construction on People.

David L. Morgan, 1988, Focus Groups as Qualitative Research, Sage Publications, London.

Edgar F. Borgatta \& Marie L. Borgatta, 1992, Encyclopedia of Sociology, vol. III, Macmillan Publisihing Company.

Eddy Ruchiyat, 1999, Politik Pertanahan Nasional sampai Orde Reformasi, Alumni, Bandung.

Effendi Peranginangin, 1986, Hukum Agraria di Indonesia, Rajawali, Jakarta.

1986, Hukum Agraria di Indonesia: Suatu Telaah dari Sudut Pandang

Praktisi Hukum, Rajawali, Jakarta.

Gouw Giok Siong, 1959, Hukum Agraria Antar Golongan, Universitas, Jakarta.

H. Muhajir Noeng, 1996, Metodologi Penelitian Kualitatif, Rakesarasin, Yogyakarta.

Jimly Asshiddiqie, 12 April 2011, Pesan Konstitusional Keadilan Sosial, Malang.

J.J. von Schmid, 1958, Ahli-ahli Pikir Besar tentang Negara dan Hukum, (terjemahan R. Wiratno, D.Dt.Singomangkuto dan Djamadi), Pembangunan, Jakarta.

John Salindeho, 2001, Masalah Tanah Dalam Pembangunan, sinar grafika, Jakarta.

, 2012, Hukum Agraria Nasional, Pustaka Margaretha, Muhadjir, Jakarta

Kartini Mulyadi \& Gunawan Widjaja, 2003, Perikatan yang lahir dari Perjanjian, Raja Grafindo Persada, Jakarta.

Kartasapoetra, 1992, Masalah Pertanahan Di Indonesia, Rineka Cipta, Jakarta.

Matthew B. Miles dan Michael Huberman, 1992, Analisa Data Kualitatif, UI Press, Jakarta.

Kartini Soedjendro, 2001, Perjanjian Peralihan Hak Atas Tanah yang Berpotensi Konflik, Kanisius, Yogyakarta.

Mudjiono, 1997, Politik dan Hukum Agraria, Liberty, Yogyakarta.

Noer Fauzi, 1999, Petani Penguasa, Pustaka Pelajar, Yogyakarta.

Notonagoro, 1984, Politik Hukum dan Pembangunan Agraria di Indonesia, Bina Aksara, Jakarta.

Nur Hasan Ismail, 1995, Proses Akumulasi Penguasaan dan Pemilikan Tanah Pertanian, dalam Buletin Mimbar Hukum, Fakultas Hukum UGM, No. 21/V/1995, Yogyakarta.

Parlindungan, A.P, 1983, Berbagai Aspek Pelaksanaan UUPA, Alumni, Bandung. 1989, Hak Pengelolaan Menurut Sistem UUPA (Undang - Undang Pokok Agraria), Mandar Maju, Bandung.

1994, Bunga Rampai Hukum Agraria Serta landreform (Bagian III), Mandar Maju, Bandung Philippe Nonet \& Philip Selznick, 1978, Law and Society in Transition: Toward Tanggapanive Law, Harper and Row Publisher, London.

1998, Komentar Atas Undang Undang Pokok Agraria, Bandung.

Patrick Mc. Auslan, 1986, Tanah Perkotaan dan Perlindungan Rakyat Jelata, Walhi \& Gramedia, Jakarta. 
Peter L.Berger, 1982, Pyramids of Sacrifice:Political Ethic and Social Change, (Terjemahan, A. Rahman Tolleng), LP3ES, Jakarta

Purbacaraka, Purnadi \& A. Ridwan Halim, 1982, Hak Milik Keadilan dan Kemakmuran Tinjauan Falsafah Hukum, Ghalia Indonesia, Jakarta.

Rikardo Simarmata, 2006, Socio-Legal Studies dan Gerakan Pembaharuan Hukum, dalam Digest Law, Society \& Development, Volume I Desember 2006-Maret 2007.

Ronald Z. Titahelu, 1993, Penetapan Asas-Asas Hukum Umum Dalam Penggunaan Tanah Untuk Sebesar-besar Kemakmuran Rakyat, Disertasi, PPS-UNAIR, Surabaya.

Robert K.Yin, 1981, Case Study Research: desain and Methods, Sage, London.

Salindeho,1993, Masalah Tanah Dalam Pembangunan, Sinar Grafika, Jakarta.

Satjipto Rahardjo, 22 Mei 1996, Membangun Negara Hukum Pancasila, Orasi IImiah pada Wisuda Sarjana Universitas Swadaya Gunung Jati, Cirebon. , 2000, IImu Hukum, Citra Adtya Bhakti, Bandung. 2008, Negara Hukum Yang Mensejahterakan, Genta, Jogjakarta.

Soedjendro, Kartini, 2001, Perjanjian peralihan hak atas tanah yang berpotensi konflik, Kanisius, Yogyakarta.

Soetiknyo, Imam, 1994, Politik Agraria Nasional: Hubungan manusia dengan tanah yang berdasarkan Pancasila, Gajah Mada University Press, Yogyakarta.

Soedharyo, 2001, Status Hak dan pembebasan Tanah, Sinar Grafika, Jakarta.

Soedjendro, JK, 2001, Perjanjian Peralihan Hak Atas Tanah yangBerpotensi Konflik, Kanisius, Yogyakarta.

Soimin, Soedharyo, 2001, Status Hak dan Pembebasan Tanah, ed. II, Sinar Grafika, Jakarta. Sunaryati Hartono, 1991, Politik Hukum Menuju Suatu Sistem Hukum Nasional, Alumni, Bandung. 1994, Penelitian Hukum Di Indonesia Pada Akhir Abad ke-20, Alumni, Bandung.Krueger, Richard A., 1988, Focus Groups: A Practical Guide for Applied Research, Sage Publications, London.

Sunggono, Bambang, 1994, Hukum Dan Kebijakan Publik, Sinar Grafika, Jakarta.

Syarif, Elza, 2012, Menuntaskan Sengketa Tanah Melalui Pengadilan Khusus Pertanahan, Kepustakaan Populer Gramedia (KPG), Jakarta.

Tanya, Bernard L., Yoan N. Simanjuntak \& Markus Y. Hage, 2006, Teori Hukum: Strategi Tertib Manusia Lintas Ruang dan Generasi, Kita, Surabaya.

Wignjosoebroto, Soetandyo, 2002, Hukum, Paradigma, Metode dan Dinamika Masalahnya, Lembaga Studi dan Advokasi Masyarakat [ELSAM], Jakarta.

William J. Chambliss dan Robert B. Seidman, 1971, Law, OrderAnd Power, Addison Wesley Publishing Company, Reading, Massachusetts. London.

Yudha B. Ardhiwisastra, 1999, Imunitas Kedaulatan Negara di Forum Pengadilan Asing, Alumni, Bandung.

\section{b. Jurnal dan lain-lain.}

Bahan Pembinaan Teknis, Seksi Hak Atas Tanah dan Pendaftaran Tanah, Sub Seksi Pengaturan Tanah Pemerintah, 18 Juni 2012

Harian Kompas, artikel dengan judul "Indonesia Butuhkan Penegakan Hukum Progresif" (Kompas, 15 Juni 2002).Profil Kabupaten Semarang, 2012. 